\title{
TALKING STICK IN SPEAKING ABILITY
}

\author{
Dewi Sartipa *) \\ dewisartipa@ymail.com \\ Pendidikan Bahasa Inggris \\ Universitas Muhammadiyah Kotabumi Lampung
}

\begin{abstract}
ABSTRAK
Tujuan dari tulisan ini adalah sebagai sumber pengetahuan pendidik dan siswa dalam meningkatkan kemampuan siswa untuk tampil berbicara dengan menggunakan teknik tongkat berbicara (Talking Stick). Pendidik dapat menggunakan Tehnik Talking Stick dalam proses pembelajaran karena Tehnik Talking Stick dapat meningkatkan kemampuan berbicara siswa dalam proses pembelajaran bahasa Inggris. Tehnik Talking Stick dalam proses pembelajaran khususnya berbicara bahasa Inggris memiliki hubungan yang erat. Tehnik Talking Stick adalah salah satu tehnik Kegiatan belajar sambil bermain. Tehnik ini adalah satu cara yang bagus untuk di aplikasikan ke dalam proses pembelajaran. Dengan adanya permainan, siswa akan senang dan terhindar dari rasa jenuh saat mempelajari suatu materi yang disajikan oleh gurunya.
\end{abstract}

Kata Kunci; Berbicara, Teknik Tongkat Berbicara

\section{INTRODUCTION}

English learning consists of learning writing, reading, listening and speaking skill. Skill is ability which is owned by the students to do something suitable with their knowledge. Speaking is the most important target of learning English as the second or the foreign language. It is very important to master speaking well in showing by experience of learning the language in our life. There are three main reasons for students to speak in the class. Firstly, speaking activities provide opportunity to practice speaking in the class. Secondly, speaking make students know in providing feedback between teacher and students. Finally, the most of students have opportunity to be active in speaking lesson.

Speaking is more difficult than other skills. Many students are fail in speaking because of their negative perception. The students think that speaking difficult lesson. Because speaking is produce the words to say something, and sometimes the students must speak up in front of class with their own word, whereas the students lack in vocabulary. 
Based on the statement above, speaking is useful skill for students, for example students can do many things such as practice speaking well with their friends, the students can practice to speak up in front of the class, and there is feedback between teacher and students in teaching speaking English.

This Article can be used as the reference for the teacher in learning English. From the statement above it can be concluded that speaking ability is skill to well deliver ideas, feelings, and use grammar, vocabulary, and pronunciation orally. The student has to be fluent in speaking, then having a lot of vocabulary in order to make them easy to speak.

\section{DISCUSSION}

In the laerning process there are many methods that can be used in the classroom. In this artickle, the writer choose Talking Stick. A talking Stick is passes around from member to member allowing only the student or person holding the stick to speak.

Speaking is one of the important skill in English, because by speaking people can deliver their ideas. According to Tarigan (1981:15) "speaking is the ability of someone in articulating words which has purpose to express, explain, and deliver the ideas, opinion and feelings".
From the explanation, the writer concludes that speaking is person's ability to say something and express their ideas, thought to get interaction to another people. Louma (2004:9), “ Speaking as interaction, and speaking as social and situation based on activity. After the students have high confidents to speak in front of the classroom, the students will be success communicate to other people in their society.

In addition, speaking is interactive process which involves face to face conversation partner and speaking is essential part of our life. Without speaking it is impossible for us exist in our environment. Richard and Renandya (2002:210) say that speaking is one of the central elements of communication. It means that speaking is very important. Speaking is the interaction between two people or more in getting information where there is a speaker and listener. By speaking someone can express his or her feeling, emotion and idea.

Every time, people always produce hundreds of words or message from our mouth. Each of words or utterances has meaning to deliver the message from the speaker. Speaker must communicate his ideas clearly so that the listener is able to receive the meaning.

$$
\text { According to Hornby }
$$
"speaking is to say something or express 
oneself in a particular language. It means that speaking is produce the words to deliver our message or to express our opinion for the listeners in a language. Besides Hornby, Bygate in Pawlak (et al) (2002:27), speaking is like same with learn incorrect language because with speaking people can using for learn other knowledges.

Skill is ability who has students to do something suitable with their knowledge. According to Hornby (1995:1109) "skill is the ability to do something well". In English there are four skills who has students mastery, they are speaking, listening, reading, and writing. One of them students must mastery speaking skill, because with speaking students can communicate with other people and the students can express their ideas.

Speaking is related with ability. Ability as quality of being able to do something. Furthermore ability is also defined as possession of the qualities required to do something, necessary skill, competence or power to cope with a problem.

Ability is the mental or physical power to do something. According to Robbins (2007:57), means the ability of person's capacity to perform a variety of individual fatherly duties in a job. Robbins further stated that the ability is a current assessment of what a person can do.

\section{Teaching Speaking}

Speaking is very important because with speaking people can communicate with another people. Because English as an international language and used by people in the world. So, at school the student have to learn English especially in speaking ability. Because with speaking the students can express their ideas and opinions. Speaking is to communicate with another people indeed with people in the world.

Teaching speaking is very important that language teachers have to pay attention when the teachers are teaching speaking. According to Tarigan (2008:16) the aim of teaching speaking is to provide students with ability to communicate efficiently. With this goal, various speaking activities can contribute a great result to students in developing speaking skills. The writer assumes that in teaching speaking, appropriate and possible talking stick method should be applied based on the purpose in order to get the better comprehension.

The teacher must know whether the speaking ability of students increases or not. Therefore, assessing speaking is important to measure the students' speaking ability. According to Weir (2005:195) there are some criteria that 
must be accounted to asses speaking such as fluency, pronunciation, grammar, vocabulary, interactional strategies.

Speakers to express their ideas. In conclusion, the writer assumes that vocabulary is part an important role in speaking

\section{The Concept of Talking Stick}

Talking stick is a technique that used to make the students feel more comfortable and enjoyable in learning language. According to Shoimin (2014:197) talking stick is the method used by American people to invite all of people or deliver opinion in a forum. It means that talking stick is a method very suitable if used in teaching speaking because it is can make students more interesting to study, spontaneously students will speak up to express their ideas.

The talking stick can be used by any number of people, through it gets really interesting when number top twenty. It means that if the talking stick plays by many students, it is more interesting for them. The talking stick was commonly used in council circles to decide who had the right to speak, (Locust,1998) Talking stick is one of method that can be used by grouping to interest the student to learn English more especially in speaking ability. Where is the stick stop the students have to speak up to express their ideas and opinions. Talking stick is used as a sign for someone to have chance to speak, which is given return.

Based on the statement above, talking stick is a technique in which students free to speak, deliver the ideas and opinion, and answer the question. And by using talking stick the students more be brave to speak up with their own word without afraid with their mistakes. For example the teacher asked student for speak up in front of the class or express their ideas based on the story or answer the question who is given by the teacher.

\section{The Strengths and Weaknesses of using Talking Stick}

According to Shoimin (2014:199) by using talking stick also have the strengths and weaknesses, it can be seen in below:

\section{The Strengths are:}

1. Examine ready the students in learning.

2. Try the students to understanding the material.

3. Make students study hard.

4. Make students to be brave to express the opinion.

So, by using talking stick there are the advantages for the students. Because, by using talking stick to make students more be brave to express their ideas or opinions. Besides that, with this technique 
train the students to speaking and also can make funny situation.

\section{The Weaknesses are:}

1. Make students panic.

2. Make students become tense.

3. Frightened of the question would given by the researcher.

Besides the advantages, talking stick technique also has the weakness. By using talking stick to make the students panic and tense, because there is no preparation from students to answer the question from the teacher.

\section{CONCLUSION}

In clonclusion, the implementation of Talking Stick could encourage students to speak and also helped the students solve their problem in speaking. In teaching speaking, Talking stick should be taken as one of the alternative to the students. The using of Talking stick can improve the students' speaking ability. Therefore, the English teacher should be creative to manage the materials for teaching of speaking such as by using Talking stick method. The English teacher should give enough opportunity to the students to practice their speaking skill through various method, one of them is Talking stick method because it is easy to be done and it is also enjoyable for the students in learning.

\section{REFERENCES}

Hornby, As.. 1995. Oxford Advances Learner's Dictionary. New York: Oxford University Press.

Lauma, Sari. 2004. Assessing Speaking. New York: Cambridge University Press.

Locust. 1998. Native American Resources (journey Sticks and Talking Stick). Available: (http://iteslj.org/techniques/Fujioka- TalkingStick.html, (March 28 2015)

Pawlak, Miroslaw, Ewa Waniek-Klimaczk, and Jan Majer. 2011. Speaking and Instructed Foreign Language Acquisition. Great Britain: MPG Books Group.

Robbins. 2007. How to Improve Your English Ability. Bandung: Trasito.

Shoimin, Aris. 2014. 68 Model Pembelajaran Inovatif dalam Kurikulum 2013. Yogyakarta: Ar-Ruzz Media .

Tarigan, Harry Guntur. 2008. Berbicara Sebagai Suatu Keterampilan Berbahasa. Bandung: angkasa. 
Edukasi Lingua Sastra Volume 17 Nomor 2

Tarigan, Harry Guntur. 1981. Berbicara. Bandung: angkasa.

Richards, Jack C. and Willy Renandya. 2002.Methodology in Language Teaching. USA: Cambridge University Press.

Weir, Cyril. J. 2005. Language Testing and Validation. New York. Palgrave Macmillan. 